\title{
CARDINAL PATRIARCH LOUIS RAPHAEL I
}

The PRO ORIENTE Foundation has the merit of making known to many people in the East and West, our ancient Christian traditions, theology, spirituality and history that has been affected by numerous challenges including emigration.

PRO ORIENTE remains for us a sign of hope, in terms of maintaining our heritage and the reunion of sister Churches. Therefore, I am so grateful for its commitment in initiating and supporting dialogue and reconciliation among the Eastern Churches, especially the Churches of Syriac tradition.

We pray and hope always that fraternity and peace be strengthened across different regions of the Middle East, which is distracted by internal conflicts and war. However, we believe that the Christian life is founded on hope based on Jesus' words "do not be so afraid" (Mt 10:31) that encourages us to be and to remain a sign of hope wherever He has planted us.

Last but not least, I would like to salute Mar Joseph Powathil for his daring Ecclesial Leadership, his vision and wisdom. He proudly maintained the authenticity of the Eastern Church heritage in addition to his valued contribution to the research of PRO ORIENTE. May God bless him with good health and long life.

Cardinal Louis Raphael I Sako

Patriarch of the Chaldeans 